\title{
Analysis of Differences in Corporate Values and Financial Performance Three Manufacturing Industry Sectors Listed on the Indonesia Stock Exchange
}

\author{
Titi Purwantini, MM*), Endang Brotojoya \\ STIE AUB Surakarta \\ Management Lecturer \\ e-mail : Vpurwantini@ stie-aub.ac.id*)
}

2019

\begin{abstract}
The purpose of this study was to obtain empirical evidence of differences in corporate value and financial performance of the three manufacturing companies listed on the Indonesia Stock Exchange. The sample in this study were

60 manufacturing companies listed on the Indonesia Stock Exchange from 2015 to 2017. Sampling techniques were purposive sampling. The division of sector 1 consists of cement companies, basic chemicals, porcelain and glass, metals, plastics and packaging, animal feed, wood and pulp, for sector 2 consists of machinery and heavy equipment companies, automotive and its components, textiles and garments, bedding feet and cable. Whereas for sector 3 consists of consumer goods, namely tobacco, cosmetics, pharmaceuticals and household appliances. Data analysis techniques consist of normality testing and different Paired Sample Test tests. Research results prove that based on Differential Test Paired Sample Test sectors 1 and 2 Manufacturing Companies listed on the Stock Exchange have significant differences in financial performance seen from the Current Ratio and Debt Equity Ratio while from Earning per Share, Net Profit Margin and Expencess On Sales there is no difference. Based on the Different Test Paired Sample Test is seen from the Earning Per Share ratio there is a significant difference in financial performance between Sector 1 and sector 3. Based on the Different Paired Sample Test seen from the Debt Equity Ratio, there are significant differences in financial performance between Sector 1 and sector 3. There are also significant differences in the financial performance of sectors 2 and 3 from the point of view of Earning Per Share. Based on the Different Paired Sample Test Test, there was no difference in company values in the three manufacturing companies listed on the Indonesia Stock Exchange

Keywords: Company Value, Financial Performance
\end{abstract}

Tujuan Penelitian ini untuk memperoleh bukti empiris perbedaan nilai perusahaan dan kinerja Keuangan tiga sektor perusahaan manufaktur yang terdaftar di Bursa Efek Indonesia Sampel dalam penelitian ini adalah 60 perusahaan manufaktur yang terdaftar di Bursa Efek Indonesia periode 2015 sampai 2017. Teknik Pengambilan sampel dengan metode Purposive Sampling. Dengan pembagian sektor 1 terdiri dari perusahaan semen, kimia dasar, Porselen dan kaca, Logam, Plastik dan kemasan, pakan ternak, kayu dan bubur kertas, untuk sektor 2 terdiri dari perusahaan mesin dan alat berat, otomotif dan komponennya, tekstil dan garmen, alas kaki dan kabel. Sedangkan untuk sektor 3 terdiri dari barang-barang konsumsi yaitu tembakau, kosmetik, farmasi dan peralatan rumah tangga. Teknik Analisis data terdiri dari pengujian normalitas dan Uji beda Paired Sample Test. Hasil Penelitian membuktikan bahwa berdasarkan Uji Beda Paired Sample Test sektor 1 dan 2 Perusahaan Manufaktur yang terdaftar di BEI memiliki perbedaan signifikan pada kinerja keuangan dipandang dari Current Ratio dan Debt Equity Ratio sedangkan dari Earning per Share, Net Profit Margin dan Expencess On Sales tidak ada perbedaan. Berdasarkan Uji Beda Paired Sample Test dipandang dari ratio Earning Per Share ada perbedaan yang signifikan pada kinerja keuangan antara Sektor 1 dengan sektor 3. Berdasarkan Uji Beda Paired Sample Test dipandang dari Debt Equity Ratio, ada perbedaan signifikan pada kinerja keuangan antara Sektor 1 dengan sektor 3.. Demikian pula ada perbedaan signifikan pada kinerja keuangan sektor 2 dan 3 dari sudut pandang Earning Per Share. Berdasarkan Uji Beda Paired Sample Test dihasilkan tidak ada perbedaan nilai perusahaan pada ketiga sektor perusahaan manufaktur yang terdaftar di Bursa Efek Indonesia

Kata Kunci : Nilai perusahaan, Kinerja Keuangan 


\section{PENDAHULUAN \\ LATAR BELAKANG MASALAH}

Kebijakan yang berkenaan dengan nilai perusahaan merupakan kebijakan investasi, yang juga merupakan investasi jangka panjang dan jangka pendek. Menurut Hidayat (2010:458) kebijakan investasi merupakan faktor penting dalam fungsi keuangan perusahaan, dimana nilai perusahaan semata-mata ditentukan oleh kebijakan investasi atau pengambilan keputusan dalam investasi. Pendapat tersebut dapat diartikan bahwa keputusan investasi itu penting, karena untuk mencapai tujuan perusahaan yaitu memaksimumkan kemakmuran pemegang saham hanya akan dihasilkan melalui kegiatan-kegiatan investasi perusahaan. Tujuan keputusan investasi adalah untuk memperoleh tingkat keuntungan yang tinggi dengan tingkat resiko tertentu. Nilai perusahaan dapat diartikan sebagai ekspetasi nilai investasi pemegang saham (harga pasar ekuitas) sebagai reaksi terhadap informasi yang diberikannya. Sehingga kesejahteraan pemegang saham dapat dilihat dari nilai perusahaan atau nilai pasar dari harga saham perusahaan (Erlina,2008:28). Nilai perusahaan yang dibentuk melalui indikator nilai pasar saham, sangat dipengaruhi oleh peluang-peluang investasi. Pengeluaran investasi memberikan sinyal positif tentang pertumbuhan perusahaan di masa yang akan datang, sehingga meningkatkan harga saham sebagai indikator nilai perusahaan (signaling theory). Maksimalisasi Nilai Perusahaan dapat dilihat melalui Struktur Modal. Struktur modal yang optimal adalah struktur modal yang dapat memaksimalkan nilai perusahaan. Menurut teori trade off, posisi struktur modal di atas struktur modal optimalnya mengakibatkan setiap pertambahan utang akan menurunkan nilai perusahaan itu.

Sementara itu dalam penggunaan dana dituntut untuk mencari alternative lain apabila penggunaan tidak dapat dilakukan. Dana atau investasi yang digunakan dapat memberikan hal positif bagi pertumbuhan perusahaan dan berpengaruh pula terhadap nilai perusahaan yang diberikan. Keputusan investasi dimulai dengan indentifikasi peluang investasi yang sering disebut dengan proyek investasi modal. dengan mengidentifikasi proyekproyek yang menjanjikan dan memutuskan berapa banyak akan diinvestasikan dalam setiap proyek. Keputusan investasi juga disebut dengan keputusan penganggaran modal, karena sebagian besar perusahaan mempersiapkan anggaran tahunan yang terdiri dari investasi modal yang disahkan. Oleh sebab itu, harus diperhatikan waktu pengembalian proyek, dana yang dibutuhkan perusahaan untuk investasi dan operasinya. Ketika suatu perusahaan perlu mendapatkan dana, perusahaan itu bisa mengundang para investor untuk berinvestasi dengan memberikan ROR yang lebih tinggi dari bunga bank (Brealey,2008).

Pengukuran Nilai Perusahaan menurut Weston dan Copelan (2004) dalam rasio penilaian perusahaan terdiri dari: PER (Price Earning Ratio) adalah fungsi dari kemampuan laba yang diharapkan di masa yang akan datang. Semakin besar PER, maka semakin besar pula kemungkinan perusahaan untuk tumbuh sehingga dapat meningkatkan nilai perusahaan. (Tandeililin 2007). Pengukuran Nilai perusahaan menurut Tobin Q ditentukan oleh Nilai pasar Equitas (Equity Market Value), Nilai buku Total Hutang (Equity Book Value) dan Nilai pasar Equitas (Equity Market Value/EMV) merupakan hasil perkalian harga saham penutupan (ClosingPrice) akhir tahun dengan jumlah saham yang beredar pada akhir tahun. Nilai perusahaan selalu berkaitan dengan kinerja keuangan sehingga perlu dipertmbangkan dalam penelitian ini adalah besarnya laba yang diwakili dengan NPM (Net Profit Margin) yang dihasilkan dalam operasional perusahaan (Operating Expences to Sales), dimana dalam perusahaan konsumsi / dagang diwakili dengan Inventory turn Over (ITO). Rasio keuangan ini diperlukan untuk melihat perkembangan perusahaan saat ini dan dampaknya masa yang akan dating. Perusahaan yang berkembang adalah perusahaan yang mengutamakan kinerja Keuangan dan Nilai Perusahaan. Kinerja keuangan adalah prestasi keuangan yang tergambar dalam laporan keuangan perusahaan yaitu neraca rugi-laba Kinerja keuangan juga menggambarkan usaha perusahaan (operation income). Kinerja Keuangan juga menggambarkan kemampuan perusahaan dalam mengelola dan mengendalikan sumberdaya yang dimilikinya. Menurut Winarni dan Sugiarso $(2005,111)$, kinerja dapat diartikan sebagai prestasi yang dicapai perusahaan dalam suatu periode tertentu yang mencerminkan tingkat kesehatan perusahaan tersebut. Kinerja dapat dikatakan juga sebagai ukuran seberapa efisien dan efektif seorang manajer atau sebuah perusahaan, seberapa baik manajer atau organisasi itu mencapai tujuan yang memadai. Ada 
banyak faktor yang mempengarui kinerja keuangan yaitu DER (Debt Equity Ratio) menunjukkan Rasio keuangan yang menggambarkan kemampuan perusahaan untuk membayar kembali hutang yang ada dengan menggunakan modal/ekuitas yang ada, disamping itu Operating Expencess On Sales menggambarkan Rasio biaya operasi terhadap penjualan memberikan suatu pengukuran efisiensi dari struktur biaya bisnis. Demikian pula dengan Net Profit Margin dan Current Ratio yang menggambarkan kemampuan perusahaan menghasilkan laba diatas biaya. Dan juga dengan mengandalkan aktiva lancar yang dimiliki.

Perusahaan Manufaktur merupakan ujung tombak dari perkembangan perekonomian. Maju mundurnya perekonomian ditentukan oleh perusahaan Manufaktur. Dalam perkembangannya 3 sektor manufaktur ini memberikan kontribusi dalam perkembangan perekonomian Indonesia. Pada sector 3 banyak produknya yang diekspor untuk meningkatkan penjualan dan ekspansi pasar, karena jika mengandalkan permintaan dalam negeri saja maka tujuan peningkatan laba /NPM dari hasil kegiatan operasional sukar dicapai. Produk Sektor 4 merupakan produk tambahan, apabila produk ini berlebih dan tidak dikonsumsi pasar dalam negeri dapat dilakukan ekspor guna meningkatkan profit. Namun pada sector 5 yang mayoritas produknya digunakan oleh konsumen dalam negeri (kebutuhan primer) diperkirakan akan tahan dalam menghadapi krisis global

\section{Perumusan Masalah}

Berdasarkan Uraian diatas rumusan penelian ini adalah : Bagaimana Analisa perbandingan Nilai Perusahaan dan Kinerja Keuangan tiga sector industry manufaktur yang terdaftar di Bursa Efek Indonesia

Tujuan Dan Manfaat Penelitian

1. Menganalisa perbedaan Nilai Perusahaan dan kinerja keuangan ketiga sector industry manufaktur

2. Dari hasil perbandingan dapat dianalisa sector maufaktur yang memberikan kontribusi terbesar

\section{Luaran Penelitian : Jurnal nasional} Tinjauan Pustaka

\section{Nilai Perusahaan}

Suatu perusahaan dikatakan mempunyai nilai yang baik jika kinerja perusahaan juga baik. Nilai perusahaan dapat tercermin dari nilai sahamnya. Jika nilai sahamnya tinggi bisa dikatakan bahwa nilai perusahaannya juga baik. Karena tujuan utama perusahaan adalah meningkatkan nilai perusahaan melalui peningkatan kemakmuran pemilik atau para pemegang saham. Nilai perusahaan dapat didefinisikan sebagai nilai wajar perusahaan yang menggambarkan persepsi investor terhadap emiten bersangkutan. Harga pasar yang tinggi membuat nilai perusahaan juga tinggi. Nilai perusahaan yang tinggi akan diikuti oleh tingginya kemakmuran pemegang saham (Husnan,2000). Nilai perusahaan yang tinggi menjadi keinginan para pemilik perusahaan sebab dengan nilai perusahaan yang tinggi menunjukkan tingkat kemakmuran pemegang saham juga tinggi. Nilai perusahaan yang tinggi akan membuat pasar percaya tidak hanya pada kinerja perusahaan saat ini namun juga pada prospek perusahaan di masa depan. Salah satu alternatife yang digunakan dalam menilai nilai perusahaan adalah dengan menggunakan Tobins'Q. Tobins'Q ini dikembangkan oleh professor James Tobin (Weston dan Copeland,2004). Rasio ini merupakan konsep yang sangat berharga karena menunjukkan estimasi pasar keuangan saat ini tentang nilai hasil pengembalian dari setiap dolar investasi incremental.

Tobins' $Q$ dihitung dengan membandingkan rasio nilai pasar saham perusahaan dengan nilai buku ekuitas perusahaan. Faktor-faktor yang Mempengaruhi Nilai Perusahaan : Earning Per Share (EPS): Earning per share atau laba per lembar saham adalah suatu analisis yang penting di dalam laporan keuangan perusahaan.Earning per share memberikan informasi kepada para pihak luar (ekstern) seberapa jauh kemampuan perusahaan menghasilkan laba untuk tiap lembar yang beredar. Dividend Payout: Ratio Kebijakan dividen adalah kebijakan yang menyangkut tentang penggunaan laba yang menjadi hak para pemegang saham. Pada dasarnya laba tersebut bisa dibagi sebagai Dividen atau ditahan untuk diinvestasikan kembali. Perusahaan bisa membagi 
Dividen dalam bentuk uang tunai atau dalam bentuk saham (stock dividen). Kebijakan dividen masih merupakan masalah yang mengundang perdebatan karena ada beberapa pendapat mengenai Dividen.Pertama, pendapat yang mengatakan dividen dibagi sebesar-besarnya (dividend relevant), Kedua, kebijakan dividen tidak relevan, dan ketiga perusahaan membagi dividen sekecil mungkin. Jika perusahaan mampu meningkatkan pembayaran dividen karena peningkatan laba, maka harga saham akan naik. Jadi, kenaikan harga saham tersebut pada dasarnya adalah sebagai akibat dari kenaikan dari laba.Pemberian dividen dimungkinkan hanya apabila perusahaan memperoleh keuntungan, namun tidak menutup kemungkinan perusahaan tetap membagi dividen meskipun perusahaan menderita kerugian. Bird in the hand Theory menjelaskan bahwa investor menyukai dividen yang tinggi karena dividen yang diterima seperti burung di tangan yang risikonya lebih kecil atau mengurangi ketidakpastian dibandingkan dengan dividen yang tidak dibagikan. Kelompok ini berpendapat bahwa peningkatan dividen akan meningkatkan harga saham yang selanjutnya berdampak terhadap nilai perusahaan. Dalam teori kebijakan dividen yang penting diperhatikan adalah apakah perubahan rasio pembayaran dividen akan mempengaruhi nilai perusahaan? Dalam dunia tanpa pajak atau biaya transaksi tidak ada, Modigliani dan Miller (1958) mengatakan bahwa kebijakan dividen tidak mempengaruhi nilai perusahaan. Dalam dunia tanpa pajak pemegang saham bersikap sama saja apakah mereka menerima arus kas sebagai dividen, atau sebagai keuntungan modal, jika kas disimpan sebagai laba ditahan. Sedangkan perusahaan dapat memilih untuk membayar dividen dari kelebihan arus kas dari operasi dan tetap menjalankan investasi yang direncanakan. Karena dana ekstra yang diperlukan dapat diperoleh dengan menerbitkan saham baru tanpa biaya penerbitan. Nilai perusahaan tidak tergantung pada kebijakan dividen, karena semua investasi yang menguntungkan dapat dilaksanakan tanpa memperhatikan pembayaran dividen.

\section{Kinerja Keuangan}

Kinerja keuangan menurut Muchlis (2000: 44) bahwa : Kinerja keuangan adalah prestasi keuangan yang tergambar dalam laporan keuangan perusahaan yaitu neraca rugi-laba dan kinerja keuangan menggambarkan usaha perusahaan (operation income). Profitability suatu perusahaan dapat diukur dengan menghubungkan keuntungan yang diperoleh dari kegiatan pokok perusahaan dengan kekayaan asset yang digunakan untuk menghasilkan keuntungan. Menurut Sucipto (2003) kinerja keuangan adalah penentuan ukuran-ukuran tertentu yang dapat mengukur keberhasilan suatu organisasi atau perusahaan dalam menghasilkan laba. Sedangkan menurut IAI (2007) Kinerja Keuangan adalah kemampuan perusahaan dalam mengelola dan mengendalikan sumberdaya yang dimilikinya. Faktor Yang mempengaruhi Kinerja : Debt Equity Ratio (DER) Rasio keuangan yang menggambarkan kemampuan perusahaan untuk membayar kembali hutang yang ada dengan menggunakan modal/ekuitas yang ada, semakin tinggi nilai ini tentunya semakin berisiko keuangan perusahaan tersebut, nilai DER umumnya maksimal adalah $150 \%$ dan untuk perusahaan multifinance adalah 600\%.Terdapat dua pendekatan yang dapat digunakan untuk mengukur nilai DER, antara lain perbandingan antara komposisi hutang jangka pendek dan hutang jangka panjang dibandingkan dengan ekuitas. Besarnya nilai DER suatu perusahaan disebabkan besarnya hutang kepada pemegang saham, untuk mengurangi nilai DER ini dapat dilakukan dengan konversi hutang pemegang saham menjadi penyertaan modal/subordinate loan.NPM (Net Profit Margin) : NPM menunjukkan perbandingan antara laba bersih dengan penjualan (Hanafi dan Halim, 2000 : 15). Rasio ini digunakan untuk menghitung sejauh mana kemampuan perusahaan yang bersangkutan dalam menghasilkan laba bersih ditinjau dari sudut total penjualannya.

NPM mengacu pada pendapatan operasional perusahaan yang terutama berasal dari kegiatan pemberian piutang . Semakin tinggi tingkat NPM menunjukkan hasil yang semakin baik (Muljono,2015:16). Selain itu rasio NPM memiliki hubungan positif dengan laba bersih (Hanafi dan Halim, 2000 : 15). Operating Expences to Sales (OES) Rasio biaya operasi terhadap penjualan memberikan suatu pengukuran efisiensi dari struktur biaya bisnis. Hal ini memberikan indikasi kemampuan sebuah bisnis untuk mengkonversi pendapatan menjadi keuntungan. Bisnis dengan rasio rendah akan menghasilkan keuntungan lebih dari yang lain (Brigham, 2007 : 36). Bila dilihat dari waktu ke waktu rasio beban operasi (EOS) dapat memberikan informasi jika manajemen dapat memperluas operasi dengan meningkatkan biaya, Inventory Turn Over (ITO)ITO mencerminkan seberapa sering persediaan perusahaan berputar 
dari system didalam suatu periode laporan keuangan yang diberikan . Pengukuran dapat dihitung untuk setiap jenis persediaan / bahan dan perlengkapan yang digunakan dalam pemberian manufaktur atau jasa. Working In Process (WIP) tidak termasuk dalam persediaan tetapi hanya produk jadi (Bierley Jacob, 2008 :54) CR (Current Ratio) Rasio CR digunakan untuk memberikan gambaran tentang kemampuan perusahaan membayar kewajiban (Hutang ). Aset jangka pendek (kas, persediaan, piutang) semakin tinggi rasio lancar perusahaan lebih baik dalam membayar kewajibannya.

\section{Metodologi Penelitian :}

Jenis data : data sekunder dengan sumber data dari

direktori Bursa Efek Indonesia. Populasi dalam penelitian ini adalah seluruh perusahaan manufaktur yang terdaftar di BEI antara tahun 2015 sampai 2017. Sampel : Perusahaan manufaktur yang memenuhi kriteria (Purposive Sampling). Sampel dari penelitian ini berjumlah 60 perusahaan manufaktur yang terbagi menjadi 3 sektor yaiu 20 perusahaan yang termasuk sektor 1, 20 perusahaan yang termasuk sektor 2 dan 20 perusahaan sektor 3

Difinisi Operasional Variabel :

Nilai perusahaan dengan rumus

$$
\mathrm{Q}=\frac{(\mathrm{EMV}+\mathrm{D})}{(\mathrm{EBV}+\mathrm{D})}
$$

Dimana :

Q : Nilai perusahaan

EMV : Nilai pasar equitas (Equity Market Value)

D : Nilai buku dari total hutang

EBV : Nilai buku dari total aktiva (Equity Book Value) Equity Market Value (EMV) diperoleh dari hasil perkalian harga saham penutupan (ClosingPrice) akhir tahun dengan jumlah saham yang beredar pada akhir tahun

Kinerja keuangan perusahaan diukur dengan

a. Current Ratio (CR)

$$
C R=\frac{\text { Aktiva Lancar }}{\text { Hitung Lancar }}
$$

b. Earning Per Share

$$
E P S=\frac{\text { Lab Operasi }- \text { Deviden saham prioritas }}{\text { Rata rata tertimbang saham biasa yang beredar }}
$$

c. Debt Equty Ratio

$$
D E R=\frac{\text { Total Hutang }}{\text { Modal (Equity) }}
$$


d. Net Profit Margin

$$
N P M=\frac{\text { Earning After Tax }}{\text { Penjualan Bersih }}
$$

e. OES

$$
O E S=\frac{\text { Biaya Operasi }}{\text { Penjualan Bersih }}
$$

\section{Teknik Analisa Data}

a) Pengujian hipotesis penelitian ini dilakukan dengan menggunakan Uji Beda Paired Sample Test dan Uji Wilcoxon Test. Apabila data yang dihasilkan terdistribusi secara normal maka akan dilakukan Uji Beda Paired Sample Test sedangkan apabila data yang dihasilkan terdistribusi tidak normal maka akan dilakukan Uji Wilcoxon Test dengan tingkat signifikansi $5 \%$.

b) Pengujian Normalitas Data.

Sebelum data yang diperoleh diolah untuk melakukan analisis, maka terlebih dahulu dilakukan uji normalitas. Uji normalitas dilakukan dengan tujuan untuk mengetahui apakah sampel yang diambil terdistribusi secara normal atau tidak. Pada penelitian ini, uji normalitas dilakukan dengan teknik One Sample Kolomogrov Smirnov Test. Uji normalitas ini berfungsi untuk menentukan alat uji statistik apa yang digunakan. Apabila data yang diuji ternyata terdistribusi normal maka akan digunakan statistik parametrik dimana hipotesis diuji dengan Uji Beda Paired Sample Test. Namun bila data tidak terdistribusi secara normal maka akan digunakan statistik nonparametric dimana hipotesis diuji dengan Uji Wilcoxon Test. Menurut Ghozali (2001) ketentuan mengenai kenormalan data diindikasikan dengan: Nilai Asymp. Sig.atau probabilitas lebih besar dari 0.05 (Sig.> 0.05) yang artinya data terdistribusi secara normal . Nilai Asympg. Sig. atau probabilitas lebih kecil dari 0.05 (Sig. $<0.05)$ yang artinya tidak terdistribusi secara normal.

\section{Pengujian Hipotesis}

Pengujian hipotesis bergantung pada kenormalan distribusi data. Apabila data terdistribusi secara normal maka hipotesis yang diajukan akan diuji dengan menggunakan Uji Beda Paired Sample Test. Apabila data yang dihasilkan tidak terdistribusi secara normal maka akan dilakukan pengujian statistik dengan Uji Wilcoxon Test dengan tingkat signifikansi 5\%. Menurut Ghozali (2001), indikator untuk Uji Beda Paired Sample Test ditentukan dengan: Nilai Asymp. Sig.lebih besar atau sama dengan 0.05 (Sig.> 0.05) atau $\mathrm{T}$ hitung lebih besar atau sama dengan $\mathrm{T}$ tabel maka terdapat perbedaan yang signifikan. Nilai Asympg. Sig. lebih kecil dari 0.05 (Sig.< 0.05) atau T hitung lebih kecil dari T tabel maka tidak terdapat perbedaan yang signifikan. Sedangkan indikator untuk Uji Wilcoxon Test menurut Ghozali (2001) ditentukan dengan: Nilai Asymp. Sig lebih besar atau sama dengan dari 0.05 (Sig.> 0.05) atau Z hitung lebih besar atau sama dengan $Z$ tabel maka terdapat perbedaan yang signifikan. Nilai Asympg. Sig lebih kecil dari 0.05 (Sig. $<0.05$ ) atau $\mathrm{Z}$ hitung lebih kecil dari $\mathrm{Z}$ tabel maka tidak terdapat perbedaan yang signifikan.

\section{Hasil Penelitian Dan Pembahasan}

Deskripsi Data Yang Disajikan Dari Hasil Penelitian Ini Adalah Untuk Memberikan Gambaran Umum Mengenai Objek Kajian Dalam Penelitian Ini Antara Lain , Terdiri Dari 60 Perusahaan Manufaktur Yang Terdaftar Di Bursa Efek Indonesia (BEI) Periode 2015 - 2017. Dimana Pengukuran Nilai Perusahaan dengan Tobin Q Dan Kinerjanya Keuangan Menggunakan 
Current Ratio (CR), Earning Per Share (EPS), Debt Equity Ratio (DER), Net Profit Margin (NPM), Operating Expences To Sales (OES).

\section{Hasil Pengujian}

Uji Normalitas

Uji Normalitas Dilakukan Untuk Menentukan Distribusi Atau Penyebaran Data Variabel Yang Digunakan Dalam Penelitian. Informasi Tentang Normalitas Data Digunakan Untuk Menentukan Alat Statistik Dalam Pengujian Hipotesis, Yaitu Jika Data Terdistribusi Secara Normal, Maka Alat Statistik Yang Digunakan Dalam Pengujian Hipotesis Adalah Uji Beda Paired Sample Test. Sementara Itu Jika Data Tidak Terdistribusi Secara Normal, Maka Alat Statistik Yang Digunakan Dalam Pengujian Hipotesis Adalah Uji Wilcoxon Test.Untuk Pengujian Normalitas Data, Penelitian Ini Menggunakan One-Sample Kolmogorov-Smirnov Test Dengan Kriteria Hasil Pegujian Jika Asym.Sig Lebih Besar Dari Tingkat Signifikansi Penelitian 5\%, Maka Data Dinyatakan Terdistribusi Normal, Tetapi Jika Asym.Sig Lebih Kecil Dari 5\% Maka Dapat Dinyatakan Data Tidak Terdistribusi Secara Normal. Berikut Ini Disajikan Hasil Pengujian Normalitas Data Rasio CR, EPS, DER, OES Dan Pengukuran Nilai Perusahaan Tobin Q

\section{Uji Beda Paired Sample Test.}

Untuk Membuktikan Adanya Perbedaan Yang Signifikan Atau Tidak Mengenai Nilai Perusahaan Dan Kinerja Keuangan 3 Sektor Perusahaan Manufaktur Yang Terdaftar Di Bursa Efek Indonesia (BEI) Periode 2015-2017 Dengan Menggunakan Uji Beda Paired Sample Test Pada Tingkat Signifikansi 5\%. Jika Nilai Asmp.Sig Lebih Besar Dari 0.05 (Sig. > 0.05) Maka Tidak Terdapat Perbedaan Yang Signifikan, Tapi Jika Nilai Asmp. Sig Lebih Kecil Dari 0.05 (Sig. < 0.05) Atau $\mathrm{T}$ Hitung < $\mathrm{T}$ Tabel Maka Terdapat Perbedaan Yang Signifikan. Berikut Ini Disajikan Hasil Pengujian Paired Sample Test :

Berdasarkan Hasil Penelitian Uji Beda Paired Sample Test Sektor 1 Dan Sektor 2 Perusahaan Manufaktur Yang Terdaftar Di BEI

1. Berdasarkan Current Ratio Dihasilkan Nilai $\mathrm{T}=2,342>2$ Dan Signifikansi 0,030 < 0,05 Yang Berarti Bahwa Ada Perbedaan Kinerja Keuangan

2. Berdasarkan CR Antara 2 Sektor Perusahaan Manufaktur Berdasarkan Ratio Earning Per Share Dihasilkan Nilai T =1,007 < 2 Dan Signifikansi 0,326 0.05 Yang Berarti Bahwa Tidak Ada Perbedaan Kinerja Keuangan Antara Sektor 1 Dengan Sektor 2 Perusahaan Manufaktur

3. Uji Beda Berdasarkan Debt Equity Ratio, Dihasilkan Nilai $\mathrm{T}=10.754>2$ Dan Signifikansi $0,000<0.05$ Yang Berarti Bahwa Ada Perbedaan Kinerja Keuangan Antara Sektor 1 Dengan Sektor 2 Perusahaan Manufaktur

4. Berdasarkan Net Profit Margin Dihasilkan Nilai $\mathrm{T}=-1,488<2$ Dan Signifikansi 0,153> 0,05 Yang Berarti Bahwa Tidak Ada Perbedaan Kinerja Keuangan Antara Sektor 1 Perusahaan Manufaktur Dengan Sektor 2.

5. Berdasarkan Ratio Expencess On Sales Dihasilkan Nilai $\mathrm{T}=0,805<2$ Dan Signifikansi $0,431>0.05$ Yang Berarti Bahwa Tidak Ada Perbedaan Sektor 1 Dengan Sektor 2 Perusahaan Manufaktur.

6. Uji Beda Tobin Q, Dihasilkan Nilai $\mathrm{T}=-1,330<2$ Dan Signifikansi 0,199 $>0.05$ Yang Berarti Bahwa Tidak Ada Perbedaan Nilai Perusahaan Antara Sektor 1 Perusahaan Manufaktur Dengan Sektor 2.

Berdasarkan Hasil Penelitian Uji Beda Paired Sample Test Sektor 1 Dan Sektor 3 Perusahaan Manufaktur Yang Terdaftar Di BEIBerdasarkan Current Ratio Dihasilkan Nilai T = 1,652 < 2 Dan Signifikansi 0,115 > 0,05 Yang Berarti Bahwa Tidak Ada Perbedaan Kinerja Keuangan Antara Sektor 1 Perusahaan Manufaktur Dengan Sektor 3. Berdasarkan Ratio Earning Per Share Dihasilkan Nilai $\mathrm{T}=-3600>2$ Dan Signifikansi 0,002 $<0.05$ Yang Berarti Bahwa Ada Perbedaan Kinerja Keuangan Antara Sektor 1 Perusahaan Manufaktur Dengan Sektor 3. Uji Beda Berdasarkan Debt Equity Ratio, Dihasilkan Nilai $\mathrm{T}=11.998>2$ Dan Signifikansi $0,000<0.05$ Yang Berarti Bahwa Ada Perbedaan Kinerja Keuangan Antara Sektor 1 
Perusahaan Manufaktur Dengan Sektor 3. Berdasarkan Net Profit Margin Dihasilkan Nilai $\mathrm{T}=-1,763<2$ Dan Signifikansi 0,094 > 0,05 Yang Berarti Bahwa Ada Perbedaan Kinerja Keuangan Antara Sektor 1 Perusahaan Manufaktur Dengan Sektor 3. Berdasarkan Ratio Expencess On Sales Dihasilkan Nilai T =0,486 < 2 Dan Signifikansi 0,633 > 0.05 Yang Berarti Bahwa Tidak Ada Perbedaan Sektor 1 Perusahaan Manufaktur Dengan Sektor 3. Berdasarkan Uji Beda Tobin Q, Dihasilkan Nilai T =0,083 < 2 Dan Signifikansi 0,935 $>0.05$ Yang Berarti Bahwa Tidak Ada Perbedaan Nilai Perusahaan Antara Sektor 1 Perusahaan Manufaktur Dengan Sektor3.Berdasarkan Hasil Penelitian Uji Beda Paired Sample Test Sektor 2 Dan Sektor 3 Perusahaan Manufaktur Yang Terdaftar Di BEI. Berdasarkan Current Ratio Dihasilkan Nilai $\mathrm{T}=-1,615<2$ Dan Signifikansi 0,123 > 0,05 Yang Berarti Bahwa Tidak Ada Perbedaan Kinerja Keuangan Antara Sektor 2 Perusahaan Manufaktur Dengan Sektor 3. Berdasarkan Ratio Earning Per Share Dihasilkan Nilai T = -3,569 > 2 Dan Signifikansi 0,002 < 0.05 Yang Berarti Bahwa Ada Perbedaan Kinerja Keuangan Antara Sektor 2 Perusahaan Manufaktur Dengan Sektor 3. Uji Beda Berdasarkan Debt Equity Ratio, Dihasilkan Nilai T = 1,918. < 2 Dan Signifikansi 0,070>0.05 Yang Berarti Bahwa Tidak Ada Perbedaan Kinerja Keuangan Antara Sektor 2 Perusahaan Manufaktur Dengan Sektor 3. Berdasarkan Net Profit Margin Dihasilkan Nilai T $=-0,531<2$ Dan Signifikansi $-0.602>0,05$ Yang Berarti Bahwa Tidak Ada Perbedaan Kinerja Keuangan Antara Sektor 2 Perusahaan Manufaktur Dengan Sektor 3. Berdasarkan Ratio Expencess On Sales Dihasilkan Nilai T $=-0,504<2$ Dan Signifikansi $0.620>0,05$ Yang Berarti Bahwa Tidak Ada Perbedaan Kinerja Keuangan Antara Sektor 2 Perusahaan Manufaktur Dengan Sektor 3. Berdasarkan Uji Beda Tobin Q, Dihasilkan Nilai $\mathrm{T}=1,523>2$ Dan Signifikansi 0,144 $>0.05$ Yang Berarti Bahwa Tidak Ada Perbedaan Nilai Perusahaan Antara Sektor 2 Perusahaan Manufaktur Dengan Sektor 3

\section{Pembahasan}

Berdasarkan Current Ratio Dihasilkan Nilai T = 2,342 $>2$ Dan Signifikansi 0,030 $<0,05$ Yang Berarti Bahwa Ada Perbedaan Kinerja Keuangan Berdasarkan CR Antara Sektor 1 Perusahaan Manufaktur Dengan Sektor 2. Perusahaan Manufaktur. Perbedaan Ini Dikarenakan Perbedaan Jumlah Aktiva Dan Jumlah Hutang Yang Dimiliki Perusahaan Yang Masuk Pada Sektor 1 Dan Sektor 2 Karena CR Merupakan Perbandingan Total Aktiva Lancar Dan Hutang Lancar Atau Hutang Jangka Pendek. Uji Beda Berdasarkan Debt Equity Ratio, Dihasilkan Nilai T = $10.754>2$ Dan Signifikansi 0,000<0.05 Yang Berarti Bahwa Ada Perbedaan Kinerja Keuangan Antara Sektor 1 Dengan Sektor 2 Perusahaan Manufaktur. Perbedaan Ini Dikarenakan Jumlah Modal Yang Dimiliki Dan Hutang Yang Harus Dilunasi Dalam Jagka Panjang. Semakin Kecil DER Berarti Perusahaan Memiliki Hutang Yang Jauh Lebih Kecil Dari Modal Yang Dimiliki. Berdasarkan Ratio Earning Per Share Dihasilkan Nilai $\mathrm{T}=-3600>2$ Dan Signifikansi 0,002 $<0.05$ Yang Berarti Bahwa Ada Perbedaan Kinerja Keuangan Antara Sektor 1 Perusahaan Manufaktur Dengan Sektor 3. Pendapatan Per Lembar Saham Antara Kelompok Perusahaan Sektor 1 Dan Sekor 3. Perbedaan Ini Bida Disebabkan Jumlah Saham Yang Beredar Lebih Banyak Atau Lebih Sedikit Dibandingkan Kelompok Yang Lain. Uji Beda Berdasarkan Debt Equity Ratio, Dihasilkan Nilai $\mathrm{T}=11.998>2$ Dan Signifikansi $0,000<0.05$ Yang Berarti Bahwa Ada Perbedaan Kinerja Keuangan Antara Sektor 1 Perusahaan Manufaktur Dengan Sektor 3. Seperti Juga Sektor 1 Dan 2 Berbeda Berdasarkan Debt To Equity. Berdasarkan Ratio Earning Per Share Dihasilkan Nilai $\mathrm{T}=-3,569>2$ Dan Signifikansi 0,002 < 0.05 Yang Berarti Bahwa Ada Perbedaan Kinerja Keuangan Antara Sektor 2 Perusahaan Manufaktur Dengan Sektor 3. Perbedaan Earning Per Share Disebabkan Karena Perbedaan Harga Saham. Berdasarkan Tobin Q Dihasilkan Tidak Ada Perbedaan Yang Signifikan Antara Sektor 1 Dan 2, 2 Dan 3 Maupun 1 Dan 3 Sehingga Dapat Dikatakan Bahwa Tidak Ada Perbedaan Nilai Perusahaan Dari Ke Tiga Sektor Perusahaan Manufaktur Yang Terdaftar Di Bursa Efek Indonesia

\section{Implikai Manajerial / Kontribusi}

Tiga Sektor Perusahaan Manufaktur Yang Terdaftar Di Bursa Efek Indonesia Memiliki Perkembangan Yang Berbeda Dalam Perekonomian Indonesia. Hal Ini Dapat Dilihat Melalui Kinerja Keuangan Yaitu :Berdasarkan Current Ratio Sektor 1 Memiliki Rasio Terbesar, Walaupun Sektor 3 Juga Besar Tetapi Lebih Banyak Yang Mengalami Penurunan, Ini 
Menandakan Bahwa Sektor 1 Lebih Baik Karena Kemampuan Membayar Hutang Jangka Pendek Maupun Jangka Panjang Yang Berarti Pula Tingkat Solvabilitas Lebih Baik. Berdasarkan Earning Per Share Dapat Dilihat Bahwa Sektor 1 Juga Lebih Baik Dari Sektor 2 Dan 3 yang Kebanyakan Mengalami Penurunan. Hal Ini Berarti Bahwa Perusahaan - Perusahaan Di Sektor 2 Dan 3 Mengalami Penurunan Dalam Harga Saham. Berdasarkan Debt To Equity Sektor 1 Lebih Baik Dalam Pengelolaan Modalnya Ini Dibuktikan Dengan Perkembangan Yang Positip Sedangkan Dua Sektor Yang Lain Kemungkinan Kekuarangan Modal Dalam Memenuhi Kewajiban Jangka Panjangnya. Berdasarkan Net Profit Margin Sektor 3 Lebih Baik Dari Sektor 1 Dan 2. Ini Menunjukkan Bahwa Sektor 3 Lebih Baik Dalam Menghasilkan Laba Dari Penjualan Produknya. Untuk Sektor 1 Dan 2 Berada Dibawahnya Dalam Menghasilkan Laba Dari Penjualan Produk. Berdasarkan Operating Expencess On Sales Perusahaan Di Sektor 1 Lebih Baik, Kemudia Disusul Sektor 3 Dan 2. Hal Ini Berarti Sektor 3 Dapat Mengelola Biaya Produksi Lebih Baik Dari Sektor 1 Dan 2. Berdasarkan Penilaian Tobin Q. Sektor 2 Memiliki Nilai Perusahaan Yang Baik Daripada Sektor 1 Dan 3. Hal Ini Berarti Harga Saham Stabil Dan Masih Banyak Diminati Oleh Stockholder.

\section{Kesimpulan Dan Saran}

Berdasarkan Uji Beda Paired Sample Test sektor 1 dan 2 Perusahaan Manufaktur yang terdaftar di BEI memiliki perbedaan signifikan pada kinerja keuangan dipandang dari Current Ratio dan Debt Equity Ratio sedangkan dari Earning per Share, Net Profit Margin dan Expencess On Sales tidak ada perbedaan. Berdasarkan Uji Beda Paired Sample Test dipandang dari ratio Earning Per Share ada perbedaan yang signifikan pada kinerja keuangan antara Sektor 1 dengan sektor 3. Berdasarkan Uji Beda Paired Sample Test dipandang dari Debt Equity Ratio, ada perbedaan signifikan pada kinerja keuangan antara Sektor 1 dengan sektor 3. Demikian pula ada perbedaan signifikan pada kinerja keuangan sektor 2 dan 3 dari sudut pandang Earning Per Share. Berdasarkan Uji Beda Paired Sample Test dihasilkan tidak ada perbedaan nilai perusahaan pada ketiga sektor perusahaan manufaktur yang terdaftar di Bursa Efek Indonesia

\section{Saran}

Perusahaan Manufaktur Sektor 1,2,dan 3 memiliki perannya masing-masing. Dalam peningkatan kinerja Keuangan perlu dilihat yang paling baik. Yang tidak memiliki perbedaan apabila diperlakukan disemua sektor seperti: Earning per Share, Net Profit Margin dan Expencess On Sales

\section{Referens}

Alfredo Mahendra DJ. 2011. "Pengaruh Kinerja Keuangan Terhadap Nilai Perusahaan (Kebijakan Dividen Sebagai Variabel Moderating) Pada Perusahaan Manufaktur Di Bursa Efek Indonesia". Tesis Program Pascasarjana Universitas Udayana Denpasar.

Alamsyah. 2006. "Analisis Rasio Keuangan dan Prediksi Kesulitan Keuangan (Financial Distress) Pada Koprasi di Kabupaten Bima”. Aksioma: Jurnal Riset Akuntansi Vol. 5 tahun 2006.

Ang, Robert (1997), Buku Pintar Pasar Modal Indonesia, Jakarta, Mediasoft Indonesia.Brealey, et al. 2008."Dasar-Dasar Manajemen Keuangan Perusahaan".The Mc.Graw-Hill Companies, Inc.

Bambang Riyanto, 2001. Dasar-Dasar Pembelanjaan Perusahaan, Edisi Keempat, Cetakan Ketujuh, Yogyakarta : BPFE

Bambang Riyanto, 2001, Dasar-Dasar Pembelanjaan Perusahaan, Edisi Keempat, Cetakan Ketujuh, Yogyakarta : BPFE.

Brealey, Richard A., Stewart C. Myers dan Alan J. Marcus, 2008. Dasar-Dasar Manajemen Keuangan Perusahaan, Jilid Kedua, Edisi Kelima, Erlangga, Jakarta. 
Brigham, Eguene F dan Houston, Joel F. 2001.ManajemenKeuangan. Jakarta: Erlangga.

Easterbrook, F. H.1984. Two Agency Cost-Explana-tion of Dividends.American Economic Review .Vol. 74. No 6. Pp 1975-1999

Erlina, 2008. Metodologi Peneltian Bisnis: Untuk Akuntansi dan Manajemen,Edisi kedua, Cetakan Pertama, USU Press, Medan

Fahrizal, Helmy. 2013. Pengaruh ROA, ROE dan IOS terhadap Nilai Perusahaan. Skripsi terpublikasi. Fakultas Ekonomi dan Bisnis UIN Syarif Hidayatullah. Jakarta

Fakhruddin dan Sopian Hadianto. 2001. Perangkat dan Model Analisis Investasi di Pasar Modal. Buku satu. Elex Media Komputindo. Jakarta

Fama, Eugene F. 1978. "The Effect of a Firm Investment and Financing Decisison on the Welfare of its Security Holders". American Economic Review : Vol. 68 PP.271- 282 Ghozali, Imam. 2006. "Aplikasi Analisis Multivariate Dengan Program SPSS".Semarang :Badan Penerbit Undip.

Gaver, Jeniffer J., dan Kenneth M. Gaver, 1993,:Additional Evidence on the Association between the Investment Opportunity Set and Corporate Financing, Dividen, and Compensation Policies. Journal Of Accounting \& Economics, 16: 125-160.

Harjito, A dan Martono. 2005. Manajemen Keuangan. Yogyakarta.

Hartanty, Ellya. "Pengaruh Struktur Modal, Pertumbuhan Perusahaan, dan Return On Investment (ROI) TERHADAP Nilai Perusahaan pada Perusahaan yang Terdaftar di Bursa Efek Indonesia periode 2008-2012”. Jurnal Jurusan Akuntansi, Fakultas Ekonomi, Universitas Maritim Raja Ali Haji (UMRAH) Tanjungpinang.

Handayani ,Wiwik dan Andi Sulistyo Haribowo. 2008. Asuhan keperawatan pada klien dengan gangguan system hematologi. Salemba Medika : Jakarta.

Hidayat, Rahmat. (2010). Cara Praktis Membangun Website Gratis :Pengertian Website. Jakarta : PT Elex Media Komputindo Kompas, Granedia

Higgins, Robert C. 2004. Analysis Financial Management. New York: McGrawHill Companies, Inc.

Husnan, S. dan Suwarsono, M. 2000. Studi Kelayakan Proyek. Edisi ke-4.Yogyakarta : Unit Penerbit dan Percetakan.

Husnan, S. 2000. Corporate Governance di Indonesia Pengamatan terhadap Sektor Korporat dan Keuangan.Makalah, Seminar Good Governance dalam Masyarakat Bisnis Indonesia, Yogyakarta, 21 Juli 2000.

Husnan, Suad. 1998. Dasar-dasar Teori Portofolio dan Analisis Sekuritas. EdisiKedua. Yogyakarta: UPP-AMP YKPN.

Husnan, Suad. 1996. TeoriPortofolio Dan AnalisisSekuritas. UPP AMP YKPNYogyakarta

Heldrachman dan Suad Husan, 2000, Manajemen personalia, Edisi 4, Cetakan Kesembilan, BPFE, Yogyakarta.

Indah Febrian, Nur, 2013. “PengaruhReturn On Equity terhadap Nilai Perusahaan dengan Pengungkapan Corporate Social Responsbility sebagai variabel pemoderasi pada Perusahaan-Perusahaan dalam Jakarta Islamic Index (JIII) Periode 2009-2011”.

Isshaq, Zangina. 2009."Corporate Governance governance, ownership structure, cash holding, and firm value on the Ghana stock Exchange". The Journal of Risk Finance,Vol.10 No.5, pp. 488-499.

Keown, Arthur J., et al. 2000. Basic Financial Management, Alih bahasa Chaerul D. Djakman dan Dwi Sulisyorini, Dasar-Dasar Manajemen Keuangan, Edisi ketujuh, Buku II, PT Salemba Empat, Jakarta. 
Monks, Robert A.G danMinow, N. Corporate Governance 3 rd edition.2003 Blackwell Publishing.

Modigliani, F \& Miller, M.H. 1958. The Cost of Capital, Corporation Finance and The Theory of Investment. The American Economic Review. 13(3): 261- 297. Mardiyanto, Handono, 2009. Intisari Manajemen Keuangan.Jakarta :Grasindo

Myers, Stewart C. (1984). The Capital Structure Puzzle. Journal of Puzzle

Myers, Stewart C. (1977). Determinant of Corporate Borrowing. Journal of Financial Economics.

McConnell, John J. \&Muscarella, Cris J. 1984.Capitalizes Value, Growth Opportunities and Corporate Capital Expenditures Announcements. Purdue University, Lafatette.

Opod Chrisna Riane, 2015. “Analisis Pengaruh Faktor-Faktor Fundamental Makroekonomi Terhadap Kinerja Keuangan Perusahaan Serta Nilai Perusahaan (Studi Kasus Pada Perusahaan Perbankan Yang Terdaftar di BEI Periode 2009- 2013”. Jurnal Program Magister Manajemen Fakultas Ekonomi Dan Bisnis Universitas Sam Ratulangi.

Paspupah, Ima,2014. "Pengaruh Ukuran Perusahaan, Profitabilitas, Tanggung Jawab Sosial Perusahaan, Kepemilikan Institusional, Pertumbuhan Penjualan dan Struktur Modal terhadap Nilai Persuahaan (Studi Empiris pada Perusahaan Properti yang masuk kedalam kelompok daftar Efek Syariah Periode 2009-2012". 